First Peoples Child \& Family Review

An Interdisciplinary Journal Honouring the Voices, Perspectives, and Knowledges of
First Peoples through Research, Critical Analyses, Stories, Standpoints and Media

Reviews

\title{
Book review : Dubinsky, K. (2010). Babies without Borders: Adoption and Migration Across the Americas. Toronto: University of Toronto Press
}

\section{Ferzana Chaze}

Volume 6, Number 2, 2011

URI: https://id.erudit.org/iderudit/1068876ar

DOI: https://doi.org/10.7202/1068876ar

See table of contents

Publisher(s)

First Nations Child and Family Caring Society of Canada

ISSN

1708-489X (print)

2293-6610 (digital)

Explore this journal

Cite this review

Chaze, F. (2011). Review of [Book review : Dubinsky, K. (2010). Babies without Borders: Adoption and Migration Across the Americas. Toronto: University of Toronto Press]. First Peoples Child \& Family Review, 6(2), 47-48.

https://doi.org/10.7202/1068876ar 


\title{
First Peoples Child \& Family Review
}

An Interdisciplinary Journal Honoring the Voices, Perspectives and Knowledges of First

Peoples through Research, Critical Analyses, Stories, Standpoints and Media Reviews

\section{Volume 6, Number 2, 2011, pp. 47-48}

\section{BOOK REVIEW: Dubinsky, K. (2010). Babies without Borders: Adoption and Migration Across the Americas. Toronto: University of Toronto Press}

\author{
Reviewed by Ferzana Chaze ${ }^{a}$
}

${ }^{a}$ Ferzana Chaze is a Doctoral Candidate at the School of Social Work, York University.

In Babies withoutBorders: Adoption and Migration across the Americas, historian Karen Dubinsky uses archival data to weave together a narrative that complicates common understandings of international and interracial adoption as either "imperialist kidnap" of children from vulnerable, poor or hapless parents, or humanitarian efforts at "rescue" of innocent children for the sake of their survival, development or spiritual salvation. By sharing her own experiences of adopting a child from Guatemala, she demonstrates how popular discourses of rescue and kidnap do not adequately describe the lived experiences of those involved. Her book discusses the manner in which the bodies of children become conduits through which a society's fears operate and the manner in which children become emblems of the nation. Adopted children become symbols on the basis of which nations and its citizens are seen to be fighting communism, imperialism, racism or lack of social progress. The book explores history through the representation of three sets of symbolic children- the "National Baby" (Cuban children during the cold war), the "Hybrid Baby" (Interracial adoptions in Canada)

Questions or correspondence concerning this book review may be addressed to:

Ferzana Chaze

Email: fchaze@yorku.ca and the "Missing Baby" (transnational adoption of children from Guatemala).

Of interest to the readers of this journal is the paradox that Dubinsky highlights between interracial adoptions of two sets of "Hybrid babies"-Black and Aboriginal children in Canada adopted by white middle class families in the 1950s-60s. She bases her analysis on adoption case records of such children from agencies in Montreal and Winnipeg respectively. Her book informs us that in the 1950's a group in Montreal began to push interracial adoptions as a symbol of Canada's racial liberalism. The adoption of hundreds of Black babies by White families that followed this advocacy effort led to a movement by which Canada began to be recognised internationally as being on the forefront of progressive interracial adoption, reinforcing commonly held notions within and outside the nation that Canada was a land of racial tolerance and civil liberty, and thus very distinct from the its Southern neighbour. Within Canada itself, these adoptions challenged previously held notions about the family and of the racial identity of children as distinct from that of its parents. Adoption of Black children by White families in Montreal came to be recognised as signifying a progressive attempt of the adoptive parents at racial integration. These Hybrid Babies became "symbolic of hope, optimism and good" (p. 66). Dubinsky contrasts the adoption of these Hybrid children with that of another group of transracially adopted children in Canada- Aboriginal children adopted into 
White families during the infamous "60's scoop." The adoption of these children has been equated with colonialism, cultural assimilation and even genocide. Dubinsky questions how and why the transracial adoptions of the two groups of Hybrid babies got such diverse reactions. She attempts to unravel possible reasons for this paradox and suggests that there could be number of explanations for the differences between the two adoption scenarios, including, the number of children placed into adoption in case of each group; the orientation and motives of the adoptive families; and, the manner in which race and racial hierarchies were understood and negotiated in the cases of the black and Aboriginal adoptees.

Dubinsky's central thesis is that that the use of grand narratives of kidnap and rescue are not useful, they allow for some voices to be heard while erasing other valid ones. Her book provides strong arguments in support of this thesis, though less persuasively in the telling of the Aboriginal children's story. Here, her attempts to complicate the kidnap narrative (commonly voiced while recounting the adoptions associated with the 60's scoop) by discussing the socio-economic factors that forced children into the adoption system, are not as effective in light of the historic repercussions faced by the Aboriginal community till this day. Many of the socio-economic factors that led to the apprehension of these children could in turn be viewed as the result of the historical oppression and marginalisation of Aboriginal communities in Canada. The strength of the book is that it allows us to view adoption, not in terms of totalising narratives, but through an accounting of history that throws light on the interrelationships between race, class and gender at one level and the individual, the state and between states at another.

Though Dubinsky is focussed on North America, there are lessons to be learned, particularly for social work practitioners in other developing countries. In countries like India, for example, where children languish in poorly funded state and private orphanages for a variety of reasons —abject poverty, abandonment, patriarchal norms that give preference to male children and/ or severe penalties to the mother of children born out of the marriage union - it might become difficult to view adoption, especially transnational adoptions as anything other than rescue. Social workers in these countries might zealously promote adoption as the only way for these abandoned/orphaned children to acquire a better future. However, Dubinsky's book allows us to question the rescue narrative even in these seemingly obvious situations. It throws light on the need to emphasise social work intervention at the preventive and developmental level. What obligation does the social work profession have to work towards ameliorating the conditions that allow for large numbers of children to be available for adoption in the first place? Should the profession be focussing more on poverty alleviation, community development, and gender equality education? Should transnational and transracial adoption be viewed as the best option or the last choice? These are some important questions for the social work profession that come to mind after reading this highly recommended book. 